\title{
Diction And Contextualization of The Jews Verses In The Holy Qur'an;Text, Translation And Commentary Of Abdullah Yusuf Ali
}

\author{
Masyithah Mardhatillah \\ IAIN Madura, Pamekasan \\ email:masyithah.mirza@gmail.com
}

\begin{abstract}
This study aims to explores Abdullah Yusuf Ali's interpreted the Jews in his The Holy Qur'an:Text, Translation and Commentary. His interpretation becomes worth to discuss due to his profile as a Moslem officer of Great Britain which politically supported the contemporary Jews in Israel. Additionally, Yusuf Ali was the big fan of the concept of inter-faith dialogue. On the other hand, he was so proud of being a Moslem so that he wrote an English translation and commentary of the Koran in order international society can understand Islam well.This paper is going to show how YusufAli put himself as a Moslem and at the same time, a Britain officer, (and also admirer) who also lived in non-Moslem milieus. The discussion will explore two parts. The first one is the diction used by Yusuf Ali to interpret the Jews verses, while the second is the contemporary contextualization on his interpretation on Jews verses into nowadays life. Using library research method through primary and secondary references combined with a hermeneutical approach, this paper comes to the following conclusion. First, there found five dictions to mention the Jews at the Jews verses, which are Jews, those who followed the Jewish law, those that stand on Judaism, those who follow the spirit of Moses and those who follow the Jewish scripture. Second, by the diverse diction, Yusuf Ali implied that The Jews is all about the spirit and physical action of individual instead of religious institution or affiliation.
\end{abstract}

\section{Keywords:}

Jews verses, Abdullah Yusuf Ali, The Holy Qur'an 


\section{Introduction}

The Jews is one of some figures told in the Koranic stories. Chronologically, it was firstly mentioned on the story of Moses when Israelities was in the exodus trip coming out from the Egypt. In addition, the Jews was also told in some next periodic stories including the era of Mohammed as they inhibited Yathrib or Madinah, a destination of hijrah that Mohammed and his followers went to. (Karim 2002) (Gabriel 2003), (Shihab 2012). Nowadays, the term Jews is also alive as mainly appears through the establishment of Israel country.

As the consequence of its long history and various events passed through, the term 'Jews' becomes difficult to define. One said that it is the most problematic term to define because of its broad relation to various things from religion, ideology, culture, nation, power and even politic (Abdullah 2007). This is then followed by several sects within the Jews itself. Some closely related terms also take a part on this confusion such as Israelities, People of the Book (abl kitab) etc. Therefore, the redefinition of the Jews, especially the Jews told in the Koranic verses, becomes an urgently academic need.

In this paper, the redefinition of the Jews will be sought from an English tafseer called The Holy Koran; Text, Translation and Commentary. What makes the book special and compatible for this discussion is because the writer himself and his life story are 'unsual'. Known as Yusuf Ali, the writer lived in a multi-cultural environment from both his academic and carrer life. By this glance, his tafseer can be asummed egalitarian and open especially for the believers of other religions. However in some extent, he was an idealistic person and this led into some inevitable clashes suffered him.

More specifically, redefining the term Jews according to Yusuf Ali becomes well-worth because of these following reasons. First, Yusuf Ali had a big interest on the Koranic stories. This made him put considerable 
space on the interpretation of historic verses (Ali 1968a). Second, Yusuf Ali was a big supporter of inter-faith dialogue (Sherif 1997) ${ }^{1}$ before being dissappointed by unexpected condition suffered him as an individual and as a Moslem. Some events in his old ages evoked a shifting paradigm on how he percieved the ideal way on how a Moslem should interact with others.

The discussion of this paper is specifically shortened and focused into two things for consideration that those two can represent how Yusuf Ali took a look at on outsider, in this sense, the Jews. Those two things are the diction used in interpreting the Jews verses and the contextualization for nowadays life. The diction is a brief description on interpretation while the contextualization is about where an interpretation guides to.

\section{Abdullah Yusuf Ali And The Holy Qur'an:Text, Translation And Commentary}

Yusuf Ali was born on April 4, 1872, as a second child in a police family. Before going to formal schools, his father taught him Arabic language and reading The Koran. Later, he enrolled his study to Anjuman e-Islam and this required him to leave home and stayed in a school dormitory. It makes sense why he never told about his mother and brother because it seems that he never got emotionally bounded with those two (Dhaouadi, n.d.). From Anjuman, he went to Wilson School and kept staying away from home. The heterogenous environment at the school made him open-minded on diversity as he interacted with multicultural people daily. Additionally, he also become a tough competitor for his fellows as he made some great achievement at school (Sherif 1997).

The hard work at Wilson School made him easier to be accepted at St. John's College which was a prestigious school at that time. He kept being

1 Yusuf Ali wrote that according to him, religions of all normal humans are actually the same, no matter how big the philosophical differences used to explain the spiritual instinct are or no matter how different a bowl to shape human's spiritual wishes. 
a great student and easily got a job at ICS or India Civil Service; a Britain institution established to assure good service for Indian people as the Britain's colony. The job put him into a dilematic position because some people thought him as a non-nationalist while he was a good worker and fully responsible on his job. However, his career run well and got better day by day. In the midst of his working years (eight teen years), in 1900, he married a Christian woman called Teresa Mary Chadlers. He had four children from this marriadge yet they were not into him especially after the divorce happening twelve years later. Eight years after it, he got married for the second time with a Moslem woman yet it failed again after the marriadge gave him a son called Rashid. The failure of those two led him into a lonely and miserable old age. He even passed away alone (Sherif 1997).

Other than ICS, Yusuf Ali also expanded his career at Islamia College serving as a headmaster (1925-1937) after venturing multiple workplaces, including Nations League in which he played various position. Having a career at Islamia College was the first time he directly and officially dedicated himself to his own country. This is important to note because after resigning from ICS - just after the Kanpur Mosque Tragedy-, he kept his dedication to The Great-Britain by serving as a multifunctional person in the midst of World War I (1914-1918).

Meanwhile, during leading the College and having concern about education, Yusuf Ali was also active in practical politic serving as a member of Unisionis party. Unfortunately, the success he got from the former was not the same as from the later. Next on, after resigning from Islamia College, he had his spare time much more so that he could broaden his intellectual reach by attending some important meetings and giving much contribution of ideas. Additionally, he also became a prominent intellectual figure proclaiming Muslim's objection on the establishment of Israel country.

In general, Yusuf Ali thought that Islam should be universal and

DINIKA, Volume 3, Number 3, September - December 2018 
compatible to various aspects of life. However, many questioned this insight because in some extent, Yusuf Ali looked secular and his religious tought tends to be apolitic. This can be seen from his political choice that he supported British authority in India instead of Khilafatis' ideology which struggled to diminish foreign's power in India, especially The Great Britain, which was considered as 'others' because of the religious and cultural differences. Because of this choice, many considered Yusuf Ali as more British than British people themselves. On the other hand, Yusuf Ali thought that India will be better under British government because two of them can complement each other. This was clearly seen from his rejection on India's independece after British was defended by Germany in World War II. However, this didn't prevent him from giving contribution of idea for building the better India after the independent day.

\section{The Holy Qur'an; Text, Translation and Commentary (THQ)}

THQ is what makes Yusuf Ali famous in international level, especially in English speaking countries. It consists of, as the name implied, text, translation and commentary of entire verses of The Koran following the structural order of mushaf Usmani and completed by some special accessories. However, some verses have translation and commentary and some others are only available in translation.

There have been about ten publishers spreading this book out through various editions either hardcopy or softcopy available both online and offline (Bangash 2015a). However, some are considered cheating for doing unethical actions just like changing the content or replacing the name of writer (and adding someone else). ${ }^{2}$ However, there are two

2 The change can be found by comparing some versions. It can be a change or distortion of some cerain parts, for example when comparing $p d f$ file from www. IslamicBulletin.org with THQ published by Dar Alarabia. In the former version, the comentary ended with $(\mathrm{R})$ indicates the missing of some original statements of Yusuf Ali. One of them is the commentary on QS. 5: 51 and QS. 5: 82. The removed parts are The trimmer loses whichever way the wheel of fortunes turn (for the first) and adalah It's true we are 
common accessories available in all version of THQ which are, special place for translation and commentary and translation of Surahs names and basmalah. So far, the most complete edition was published by Dar alArabia containing the whole accessories of THQ. It consists of prologue and epilogue for every Surah, 300 non-rythmic-lyrical prose, index and some appendixes. The Indonesian version of THQ was published by Litera AntarNusa in 2009 although it is hard to find the book and the writer mentioned at the book is Yusuf Ali and Ali Audah.

Yusuf Ali confirmed that his main purpose for writing THQ is providing English translation for international society so that they can know Islam better and easier (Ali 1968a). However, some assumed that the writing is of special interest and tendency because of traumatic experiences Yusuf Ali had during his lifetime (Ali 1968a). In spite of that, it is important to notice that the intellectual ability, position as a headmaster of Islamia College and interest on cultural story at the Koran enabled and motivated him to begin and finish his monumental work (Sherif 1997).

The very early version of THQ had been published monthly since 1934 by Muhammad Ashraf Press. Two years later, the complete version was issued and four years next, the text had been published in the UK and USA. Yusuf Ali also made three-time revision of the book and the last version also included testimonies of readers completed with his feedback.

As for the main characters of how Yusuf Ali made his commentaries are, mentioning asbab al-nuгul (Ali 1968a), inserting narration on historic verses (Ali, n.d.), making simple and short explanation on law and divine verses (Ali 1968a), using single or plural pronoun for the first speaker so it becomes more communicative, using reference code for explaining the same thing for avoiding repetition of explanation (Ali, n.d.), clarifiying those who are meant by pronoun (Ali, n.d.) and balancing the data from

Christian. We understand your point of view and we know you are good men. They are Moslem at heart, whatever their label may be (for the second).

DINIKA, Volume 3, Number 3, September - December 2018 
any reference with private comments (Hijazi 2015).

From its readers, THQ gets both positive and negative testimonies. The very clear evidence of positive testimony is the wide use of THQ as references for academic purposes this far (Hijazi 2015). There is still no special book or writing aimed to criticize or falsify the THQ as well. The various versions of THQ also show that it attracts readers' attention well for its flexible use for various purposes. Saudi Arabia government even recycled THQ as the official English translation of The Koran although the name of Yusuf Ali is not mentioned as the writer.

So far, the criticism on THQ is more related to Yusuf Ali himself instead of the content of THQ. It is possibly caused by some factors including the idea that Yusuf Ali didn't master Arabic language well (Sherif 1997), some private problems of Yusuf Ali considered as the background of book writing (Ali 1968a), the controversial view of Yusuf Ali due to his dedication on the Great Britain (Sherif 1997) and the assumption that Yusuf Ali couldn't get lesson learned from his own commentaries (Bangash 2015b).

\section{The Distribution of Jews Verses}

It makes sense why The Koran mentions the Jews in its verses multiple times. The very basic reason is because the Jews was one of inhabitants of Yathrib in which Rasulullah and Moslems at that time went to after leaving Macca through the hijrah event. Morever, the Jews is closely related with some figures or groups mentioned in the story of The Koran, such as Moses and Israelities. On the other hand, one said that the story of the Jews at The Koran is a persuative step to make the Jews embraced Islam as it completes and perfects some previous revelations including what Jews had (Gabriel 2003).

Just like other figures in the Koranic stories, the story of the Jews 
is not mentioned in one Surah only. It spreaded on some Surahs and not told in a chronological order. Uniquely, The Koran doesn't use one name or diction to describe the Jews. There are some dictions used and they can be devided into three categories, which are direct, semi-direct and indirect-concept. The first consists of some dictions derivating from $b-w-d$, the second contains other groups outside the Jews which are still closely connected to the Jews and the third is the nature or characteristic of the Jews. This division involves not only morphological tool but also theological and historical views. Information from some Quranic commentaries is also very helpful.

As for the direct concept contains of Alladrina Hadu, mentioned in 2: 62, 4: 46 and 160, 5: 41, 44 and 69, 6: 146, 16: 118, 22: 17 and 62: 6 (Albaqi, n.d.: 941), Hud as shown in 2: 111, 135 and 140 (Albaqi, n.d.: 946), and al-yabud or yahudiyyan cited on 2: 113 and 120, 5: 18, 51, 64 and 82 and 9: 30 (Albaqi, n.d.: 1048). Meanwhile, the semi-direct concept has Bani Israel referred in 5: 110 (Ali 1968b: 277), 26: 197 (Ali 1968b: 970), 27: 76, 43: 59, 46: 10, and 61: 6 and 14 (Ali 1968b) and Abli Kitab or People of The Book.

The diction of abli kitab is considered having a close connection with the Jews based on three reason. First, verses mentioning People of The Book then followed by verses telling about the Jews and slightly show that Jews is a part of People of The Book, as found in 3: 64-78, 5: 1519, 59-71 and 77-86 (Ali 1968b). Second, it is known from asbab al-nuzul or the condition of revelation that the figure told is the Jews and or one part/sect of Jews, as mentioned on 33: 26-27 (Ali 1968b: 1111-1112), 59: 2-17 and 98:1-6 (Ali 1968b: 1520-1526). Third, a verse followed by another verse telling an event that is so closely related to the Jews, as 4: 153-159 (Ali 1968b: 228-230) telling about the controversy of Jesus' death. Lastly, the third division is the character or nature of the Jews consisting of $\mathrm{Al}$ sufaha in 2: 142 and Al-mujrimun in QS. 26: 200.

\section{Dictions on Jews Vers on Interpretation of Yusuf Ali}

DINIKA, Volume 3, Number 3, September - December 2018 
As the dictions used by the Koran to describe the Jews, Yusuf Ali also had some dictions in interpreting the Jews through either his translation or commentary. However, as the characteristic of his interpretation, he seems to avoid any repetition, so that he only distinguished the use of diction in few parts instead of all parts in the Jews verses. For most of Jews verses, he simply used 'a Jew' or 'Jews', yet in making commentaries of Jews verses using Alladina Hadu, he used different dictions. First, Jews (general meaning and negative connotation); as in his translation on 5: 44, 4: 46 and 160, 5: 41 and 16: 118. Second, Those who followed the Jewish Law (negative connotation); as appears in the translation of 6: 146. Third, Those that stand on Judaism (negative connotation); as told in the translation of 62: 6. Fourth, Those who follow the spirit of Moses (positive connotation), also in translation of 62: 6. Fifth, Those who follow the Jewish (scripture) (positive connotation); as used in translating 2: 62, 5: 69 and 22: 17.

This division more or less shows that Yusuf Ali avoids generalization in his commentaries. If not so, he wouldn't have interpreted one same word using different dictions. Moreover, he also likes to confirm that what is meant by 'Jews' is not all parts or 'members' of the Jews, but some of them. This is clear from his commentaries on 4: 46 and 160, in which he used 'of the Jews' and when interpretating QS. 5: 41 using 'among the Jews'. These examples can be generalized into his other interpretation that Yusuf Ali was very careful by not making any generalization. Having delivered his ideas indirectly_through different dictions—on those examples, unfortunately, he only made a very few explanation beyond the style and diction he used.

In a direct way, Yusuf Ali clearly unveiled his ideas on the Jews in the commentary of. 6: 26-mentioning People of The Book-by distinguishing those standing on Judaism and those with The Spirit of Moses. He explained that the former group consists of those who consider 
themselves as the chosen people, the heir of divine teaching and so that freed from any punishment eventhough they do bad deeds. The mindset then led the people to be arrogant and telling a lie. At opposite, the later group, according to him, is antithesis from another one because they didn't consider about the status and didn't do the same. This small example shows that Yusuf Ali tended to interpret Judaism as negative and different from The Spirit of Moses which, in some extent, became a basic of Judaism religion.

Therefore, here are the keywords Yusuf Ali used in implying how he interprets Jews mentioned in the stories of The Koran, stand on; Judaism; the Spirit of Moses; follow/followed; Jewish Law; Jewish Scripture; Jews.

Among those, Yusuf Ali used the sense of diction, connotation and tenses to distinguish each other. The first keyword means a reliance on something else (Hornby 2008) and was used to translate 62: 6 combined with Judaism which is the second one. Hence, it can mean embracing Judaism as a formal religion or enliven its values. The use of the tenses 'present' indicates that those who are mentioned in the verse are still standing on the same thing. In the interpretation of the verse, Yusuf Ali clearly differentiated between 'Judaism' as a product and The Spirit of Moses (Yusuf Ali didn't mention what The Spirit of Moses consists of), the third keyword, as the 'origin' or 'essence'.

Concerning to the fourth keyword, Yusuf Aliimplied his interpretation in the sense of tenses. Slightly, he considered Jewish Law, the fifth keyword and Jewish Scripture, the sixth keyword (there are no explanation on those two as well), as the same. Therefore, he distinguished between those who still follow the Jewish Scripture and those who followed the Jewish Law. The former grup with simple present was still in their obedience while the latter with simple past was not anymore. As for the last keyword, Jews, was used to describe Jews in either general or negative meaning excluding the positive connotation. It seems that Yusuf Ali used 'special way' to show

DINIKA, Volume 3, Number 3, September - December 2018 
the Jews in their positive aspect.

\section{A Hermeneutical Approach:The Contextualitation on Jews Verses According to Yusuf Ali}

One of the things that hermeneutics does is unveiling what is implied by a writer considering him/her as a self especially in the relation with the topic he/she is talking about. In the sense of Yusuf Ali's interpretation on the Jews, there are many things beyond to highlight as Yusuf Ali didn't explain much about some keywords in the different dictions he used. The very first thing is about the authentic Jews and non-authentic Jews. By using the different dictions, Yusuf Ali tried to distinguish those two groups based on how they dealt with The Spirit of Moses, Judaism, Jewish Law and Jewish Scripture.

Among those four, it is only Judaism which Yusuf Ali explored in his writing. According to him, Judaism is a religion established in Palestine some centuries after Moses so that it was named as Moses' religion (Ali, n.d.). In a different place, he wrote that by its followers, Judaism was made as a formalistic religion for legitimating racial superiority (Ali 1968b). The explanation shows that Judaism is a product and the essence or the origin of it is something else. He also implied the big difference between the origin(s) and the product by attributing positive connotation on the origins of Judaism such as The Spirit of Moses, Jewish Law and Jewish Scripture and the negative one for Judaism itself.

The Spirit of Moses can mean liberation (as shown in the exodus of Israelities from Egypt and the tyranic Paraoh regime), prosperity (through his divine ability to poor out water by striking his stick) and orderliness (in confronting with Paraoh and managing the Exodus trip). Therefore, those who struggle to enliven these spirits are the real Jews, in this sense, because it stands on the origin of the Jews.

Meanwhile, the idea about Jewish Scripture is clear from one of the 
appendixes of THQ titling 'On The Taurat'. Yusuf Ali mentioned that Taurat today can be traced back into the era of Ezra and not into Moses's period, so that it cannot be said as Jewish scripture. He also mentioned that one of contents of Jewish scripture is the confirmation of Mohammad's status as prophet (Ali 1968b: 58). Hence, these statemtens imply that Jewish scripure is not available today and those who confess Muhammad's prophecy is a part of the real followers of Jewish scripture. This also makes more sense why he preferred to use scripture better than book, guide and so on. Based on this, the real or authentic Jews is those who believe in Muhammad's prophecy and anything told in so called Jewish scripture.

As for the keyword Jewish Law, Yusuf Ali didn't explain anything about it. He only considered it the same as Mosaic Law in the interpretation on 2: 83 and this can have a wider meaning. Mosaic law is closely related to Ten Commandments wich is well recorded in The Koran 2: 83-84 and 6: 151-153. Those ten contain guides in both vertical and horizontal relations to Allah, parents, children, the poor and people in general.

\section{Conclusion}

The way Yusuf Ali interpreted the Jews in The Koran is one real example on how a text is inseparable with the writer and his/her own surrounding. It is true that he faced several events in his lifetime concerning with the interaction with followers of other religions. However, it can't be denied that this rythm of life eventually led him into an open-minded view in looking at others. Apparently, he liked to assess a person through his/her private figure rather than any affiliation or religion connected to. Therefore, there is no doubt on him to imply that a term, such as Jews, can produce different types of persons.

More specifically, he used five terms as well as dictions to mention the Jews consisting of Jews, those who followed the Jewish law, those that stand on Judaism, those who follow the spirit of Moses and those 
who follow the Jewish scripture.The different dictions are not only about diverse terms, but also implication on contemporary contextualization. By this, Yusuf Ali implied about the authentic and non-authentic Jews. The former follows the origin revelation, obey the law and do good for people and themselves. Otherwise, the later considers themselves having a privelege to freed from any punishment so that they do bad deeds, tell a lie and become arrogant. He also stressed that the non-authentic Jews doesn't have to be a Judaism follower because by having some criterias of the authentic one, they can be the authentic Jews. Likewise, non-Judaism followers can be non-authentic Jews if having characteristics fitting with above mentioned. The Jews, thus, is all about the spirit and physical action of individual instead of religious institution or affiliation.

\section{References}

Abdullah, Zulkarnain. 2007. Yahudi Dalam Alqur'an: Teks, Konteks Dan Diskursus Pluralisme Agama. Yogyakarta: eLSAQ Press.

Albaqi, Muhammad Fu'ad 'Abd. n.d. Mu'Jam Mufahras Li Alfaz, Alqur'an Bi Hasyizah. Beirut: Dar Alma’rifat.

Ali, Abdullah Yusuf. n.d. "On the Taurat." In The Holy Qur'an; Text, Translation, and Commentary.

- n.d. "The Glorious Quran; The Meaning of The Glorious Quran." In Text,Translation and Commentary.

_. 1968a. "Preface to The First Edition 1934." In The Holy Qur'an; Text, Translation, and Commentary, edited by Abdullah Yusuf Ali, iv. Beirut: Dar Alarabia.

- 1968b. The Holy Qur'an: Text, Translation, and Commentary. Beirut: Dar Alarabia.

Bangash, Zafar. 2015a. "A Biography of Abdullah Yusuf Ali.” Http:// Www.Renaissance.Com.Pk/Jabore96.Html. 2015. 
2015b. "A Biography of Abdullah Yusuf Ali.” Www.Renaissance. Com. 2015.

Dhaouadi, Mahmoud. n.d. "Book Review 'Searching for Solace: A Biography of Abdullah Yusuf Ali, Interpreter of Qur'an." The American Journal of Islamic Social Sciences 14 (1): 118.

Gabriel, Mark A. 2003. The Unfinished Battle: Islam and the Jews. Florida: Charisme House.

Hijazi, Abu Tariq. 2015. "Abdulllah Yousuf Ali The Great Scholar of Holy Quran.” Www.Urdubandhan.Com. 2015.

Hornby, A S. 2008. Oxford Advanced Leaner's Dictionary of Current English. Oxford: Oxford University Press.

Karim, Khalil Abdul. 2002. Hegemoni Quraisy: Agama, Budaya, Dan Kekuasaan. Edited by M. Faishol Fatawi. Yogyakarta: LKiS.

Sherif, M. A. 1997. Jiwa Yang Resah; Biografi Yusuf Ali: Penerjemah Dan Penafsir Alqur'an Paling Otoritatif Dalam Bahasa Inggris. Edited by Rahmani Astuti. Bandung: Mizan.

Shihab, M. Quraish. 2012. Membaca Sirah Nabi Muhammad Saw Dalam Sorotan Alqur'an Dan Hadith Shabih. Jakarta: Lentera Hati.

DINIKA, Volume 3, Number 3, September - December 2018 